\title{
PHOTOSTABILITY OF TIO -COATED WOOL FIBERS EXPOSED TO ULTRAVIOLET B, ULTRAVIOLET A, AND VISIBLE LIGHT IRRADIATION
}

\author{
Qi Tang, Hui Zhang*, Ye Han, Dou Wang, Hailiang Wu \\ School of Textile Science and Engineering, Xi'an Polytechnic University, Xi'an, China \\ *Corresponding author. E-mail: hzhangw532@xpu.edu.cn
}

\begin{abstract}
:
This study is to investigate the role of the coating of $\mathrm{TiO}_{2}$ nanoparticles deposited on wool fibers against highintensity ultraviolet $B(U V B)$, ultraviolet $A(U V A)$, and visible light irradiation. The properties of tensile and yellowness and whiteness indices of irradiated $\mathrm{TiO}_{2}$-coated wool fibers are measured. The changes of $\mathrm{TiO}_{2}$-coated wool fibers in optical property, thermal stability, surface morphology, composition, molecular structure, crystallinity, and orientation degree are characterized using diffuse reflectance spectroscopy, thermogravimetric analysis, scanning electronic microscopy, energy-dispersive $X$-ray spectroscopy, Fourier-transform infrared spectroscopy, and X-ray diffraction techniques. Experimental results show that the tensile properties of anatase $\mathrm{TiO}_{2}$-coated wool fibers can be degraded under the high-intensity UVB, UVA, and visible light irradiation for a certain time, resulting in the loss of the postyield region of stress-strain curve for wool fibers. The coating of $\mathrm{TiO}_{2}$ nanoparticles makes a certain contribution to the tensile property, yellowness and whiteness indices, thermal stability, and surface morphology of wool fibers against high-intensity UVB, UVA, and visible light irradiation. The high-intensity UVB, UVA, and visible light can result in the photo-oxidation deterioration of the secondary structure of $\mathrm{TiO}_{2}$-coated wool fibers to a more or less degree. Meanwhile, the crystallinity and orientation degree of $\mathrm{TiO}_{2}$ coated wool fibers decrease too.
\end{abstract}

\section{Keywords:}

$\mathrm{TiO}_{2}$-coated wool fibers, ultraviolet rays, visible light, structure, property

\section{Introduction}

It is well-known that the prolonged exposure of wool fibers to sunlight, particularly ultraviolet (UV) rays, can result in the photo-yellowing, photo-tendering, and photo-degradation of wool [1]. Consequently, an increase in surface roughness and loss of mechanical strength of wool fibers will happen [2], which are greatly influenced by the wavelength of incident radiation [3]. The visible light radiation in sunlight causes the photo-bleaching of wool, while the UV irradiation causes the photo-yellowing [4]. The resulting changes of irradiated wool in color, physical, and chemical properties are mainly attributed to the cleavage of peptide and disulfide bonds, the oxidation or elimination of small molecules, and the formation of new crosslinks [5]. It has been reported that the short-wave ultraviolet $C$ (UVC, 200-280 nm) radiation selectively oxidizes the surface of wool fibers to produce thiol and S-sulfonate $\left(-\mathrm{S}_{-} \mathrm{SO}_{3}^{-}\right)$groups [6]. In contrast, the performances of dyeability, printability, and shrink resistance of wool fabrics could be improved to a larger extent by exposure to UV-ozone environment under mild thermal conditions [7]. The dyeing kinetic, bath exhaustion, and good fastness to rubbing can be improved when wool fabrics are pretreated with UV radiation [8].
Some pioneering studies show that the photo-yellowing and photo-tendering of wool are primarily caused by the higher energy UV rays below $310 \mathrm{~nm}$. On the contrary, others claim that the most effective yellowing waves are either in 340-420 or $320-400 \mathrm{~nm}$ region $[9,10]$. It is generally recognized that the chromophores absorbing between 250 and $320 \mathrm{~nm}$ region exist in the form of aromatic amino acid residues, for example, tryptophan, tyrosine, phenylalanine, and cystine [11]. These photo-induced chromophores are derived from tryptophan and tyrosine of wool keratins [12]. It has been demonstrated that UV rays make wool surface damage to some extent in a short time, whereas the inner cortical components are impaired in prolonged exposure [13]. Moreover, the photo-yellowing of the wool cuticle is much more easily noticeable than that of cortical fibrils [14]. The photo-stabilities of wool fabrics modified with helium gas plasma, papain enzyme, acylation and acid anhydride, and permanganate oxidation under the long-wave ultraviolet A (UVA; 320-400 nm) and short-wave ultraviolet B (UVB; $280-320 \mathrm{~nm}$ ) rays, and blue light irradiation are highly dependent upon the modification type [15]. More recently, the photo-yellowing mechanisms of wool and the current strategies for improving wool's photostability have been systemically summarized [16]. 
The photo-degradation prevention treatments of wool have been extensively investigated using organic polymeric UV absorbers [17-19] and inorganic UV blockers, such as $\mathrm{TiO}_{2}$ $[20,21]$ and $\mathrm{ZnO}[22,23]$, or by dyeing and mordanting with alum and ferrous sulfate [24] in recent years. As an ideal semiconductor photocatalyst, anatase titanium dioxide $\left(\mathrm{TiO}_{2}\right)$ nanoparticles are of great interest because of their impressive features, such as nontoxicity, physicochemical stability, good reflective, UV absorption ability, and high photocatalytic reactivity [25]. According to the solid band theory, there are two likely reaction mechanisms of $\mathrm{TiO}_{2}$, which acts as UV-blocking additive, under UV rays for the consumption of generated active species: they can react with other active electrons and holes and then being trapped by the absorbents surrounding $\mathrm{TiO}_{2}$ and initiating a series of reduction and oxidation reactions [26]. For instance, to gain the anti-shrinkage [27], self-cleaning [28], anti-UV [29], antibacterial [30], and moth-proofing properties $[31,32]$, wool fabrics or fibers have been treated with nano$\mathrm{TiO}_{2}$ sol in combination with chitosan and polycarboxylic acid [33] to increase the binding force of $\mathrm{TiO}_{2}$ nanoparticles on wool surface, or with $\mathrm{TiO}_{2}$ sol and poly(sodium 4-styrene-sulfonate) [34] by layer-by-layer self-assembly technology. The UV exposure experiments reveal the photo-oxidation, and hence the degree of photo-yellowing of wool keratin is significantly determined by the dose of absorbed UV radiation [35] and the concentrations of $\mathrm{TiO}_{2}$ [36]. The alkali solubility of the nano$\mathrm{TiO}_{2}$-coated wool fabrics can be reduced while the fabric becomes more hydrophilic [37]. $\mathrm{TiO}_{2}$ nano-photo-bleaching has been applied to the scoured and protease pretreated wool fabrics; thus, the improved whiteness index and hydrophilicity can be obtained [38].

More previous studies have reported that the wool fabric has been fabricated by in situ synthesis of $\mathrm{N}$-doped $\mathrm{TiO}_{2}$ under ultrasound irradiation [39]. The polyester/wool blended fabric has been treated with proteases and lipases [40] or oxygen plasma [41] to enhance the anchoring of nano- $\mathrm{TiO}_{2}$ on the fabric surface. $\mathrm{TiO}_{2}$ nanoparticles co-doped with nonmetal/ metal have been deposited on the surface of photo sonotreated wool fabric using titanium isopropoxide, silver nitrate, and ammonia [42]. Research has been undertaken to reduce the photocatalytic activity of $\mathrm{TiO}_{2}$ by depositing a layer of $\mathrm{SiO}_{2}$ shell on $\mathrm{TiO}_{2}$ nanoparticles, which are anchored on wool fabrics to improve the photo-yellowing of the wool [43].

However, it is worth mentioning that the radiation wavelength and dose relating to tensile and yellowness and whiteness of wool fibers are missing in most previous studies. Also, little is known about the effects of high-intensity short-wave UVB and long-wave UVA rays on the structure of wool fibers. Although $\mathrm{TiO}_{2}$ has been widely used as inorganic UV blockers, the influences of $\mathrm{TiO}_{2}$ coating on the properties of wool fibers have not been investigated in detail except a few studies [44]. The purpose of this study is to clarify whether the coating of $\mathrm{TiO}_{2}$ nanoparticles could protect wool fibers from the prolonged exposure to high-intensity UVB, UVA, and visible light. The influences of UVB, UVA, and visible light on various tensile, yellow and white indices, morphology, molecule structure, crystallinity, orientation, and thermal stability of $\mathrm{TiO}_{2}$-coated wool fibers are discussed.

\section{Materials and methods}

\subsection{Materials}

The 80s Merino wool fibers were friendly provided by Shandong Ruyi Technology Group Co., Ltd., in China. The average linear density of the as-obtained wool fibers was measured to be $3.48 \pm 0.04$ dtex. The chemical reagents were of analytical grade and included tetraisopropyl titanate $\left(\left(\mathrm{CH}_{3} \mathrm{CH}_{3} \mathrm{CHO}\right)_{4} \mathrm{Ti}\right.$, CAS: 546-68-9), sodium carbonate $\left(\mathrm{Na}_{2} \mathrm{CO}_{3}\right)$, anhydrous ethanol $\left(\mathrm{CH}_{3} \mathrm{CH}_{2} \mathrm{OH}\right)$, and acetone $\left(\mathrm{CH}_{3} \mathrm{COCH}_{3}\right)$. The deionized water was used in the whole experiment.

\subsection{Fabrication of $\mathrm{TiO}_{2}$-coated wool fibers}

The $\mathrm{TiO}_{2}$-coated wool fibers were prepared by immobilizing of $\mathrm{TiO}_{2}$ nanoparticles on wool fibers using tetraisopropyl titanate as the precursor under hydrothermal condition. Before modification with $\mathrm{TiO}_{2}$, according to the material-to-liquor ratio of $1: 20,5 \mathrm{~g}$ of wool fibers was first immersed in $100 \mathrm{ml}$ of sodium carbonate $(2 \mathrm{~g} / \mathrm{l})$ aqueous solution at $50^{\circ} \mathrm{C}$ for $120 \mathrm{~min}$ and then dipped successively into deionized water, acetone, and anhydrous ethanol solution at $50^{\circ} \mathrm{C}$ for $10 \mathrm{~min}$, followed by washing with deionized water thrice and finally dried in an oven at $50^{\circ} \mathrm{C}$. Next, $0.5 \mathrm{ml}$ of tetraisopropyl titanate was completely dissolved in $10 \mathrm{ml}$ of anhydrous ethanol solution at room temperature, and $70 \mathrm{ml}$ of deionized water was then added under vigorous magnetic stirring. The pretreated wool fibers $(0.5 \mathrm{~g})$ were soaked in the above mixture solution at ambient temperature for $10 \mathrm{~min}$. The wool fibers along with the suspension were subsequently transferred into a $100-\mathrm{ml}$ polytetrafluoroethylene reaction vessel, which was enclosed in a stainless steel tank. The tank was set in a reactor and was run at a speed of $60 \mathrm{rpm}$. At the same time, it was heated up to $110^{\circ} \mathrm{C}$ at a heating rate of $2^{\circ} \mathrm{C} / \mathrm{min}$ and kept for $1.5 \mathrm{~h}$ at $110^{\circ} \mathrm{C}$. After that, the wool fibers were washed alternately twice with deionized water and anhydrous ethanol at room temperature for $10 \mathrm{~min}$ each time and finally dried at $50^{\circ} \mathrm{C}$. The original and tetraisopropyl titanate hydrothermal-treated wool fibers were designated as W1 and W2 specimens, respectively.

\subsection{Wool fibers exposed to UVB, UVA, and visible light irradiation}

The laboratory-accelerated irradiation testing was employed to assess the effect of $\mathrm{TiO}_{2}$ coating on the structure and properties of wool fibers under three high-intensity radiation sources, namely UVB ray (280-320 nm), UVA ray (320-400 nm), and visible lights. The erythemally weighted UV irradiance (or DUV) was typically around $0.025 \mathrm{~mW} / \mathrm{cm}^{2}$ in midday summer sunlight; thus, a Philips TL18W/10 UVB lamp (20 W) with the main wavelength of $365 \mathrm{~nm}$ was used to produce the long-wave UVA rays, and its irradiance was measured to be $0.26 \mathrm{~mW} /$ $\mathrm{cm}^{2}$ by a TM-213 UV meter (Tenmars Electronics Co., Ltd., Taiwan), which is about 10 orders of magnitude larger than that of the DUV. Meanwhile, to cause greater damage to wool fibers, three Philips TL 20W/01 lamps (20 W for each) with the main wavelength of $311 \mathrm{~nm}$ were used to produce high energy short-wave UVB rays, and its irradiance was measured to be $0.7 \mathrm{~mW} / \mathrm{cm}^{2}$. For visible light irradiation, a metal halide light 
(800 W) was used to simulate the visible light and UV rays were blocked out by the UV filter. The luminous intensity was measured to be 59,500 Ix by a TES-1332A digital light meter (TES Electrical Electronic Corp., Taiwan). A thin layer of wool fibers was exposed to UVB, UVA, and visible light irradiation for a specific period of time. The distances between irradiation sources and wool fibers were set at $10 \mathrm{~cm}$. To explore the effects of irradiation intensity on the tensile properties, the wool fibers were exposed to one $\left(0.49 \mathrm{~mW} / \mathrm{cm}^{2}\right)$, two $\left(0.62 \mathrm{~mW} / \mathrm{cm}^{2}\right)$, and three $\left(0.7 \mathrm{~mW} / \mathrm{cm}^{2}\right)$ UVB lamps for $48 \mathrm{~h}$.

\subsection{Measurement and characterization}

\subsubsection{Measurement of tensile property}

The tensile properties of wool fibers were performed on a YG(B)006 electric single fiber strength machine (Ningbo Textile Instrument Factory, China) at a constant rate of $10 \mathrm{~mm} / \mathrm{min}$ in accordance with ISO 5079:1996 standard. The clamping length was $10 \mathrm{~mm}$ and the pretension was $0.1 \mathrm{cN}$. The mean values were calculated by measuring more than 300 wool fibers to ensure a $95 \%$ confidence level.

\subsubsection{Measurements of yellowness and whiteness indices}

The yellowness and whiteness indices of wool fibers were conducted on a Datacolor SF300 spectrophotometer according to the ASTM E-313 standard. CIE standard illuminant $D_{65}$ with $10^{\circ}$ observer was used. The average values were recorded by measuring five independent measurements.

\subsubsection{Optical property analysis}

The diffuse reflectance spectra of wool fibers were recorded on a Perkin-Elmer Lambda 950 UV-vis-NIR spectrophotometer using an integrating-sphere accessory over the range of 200 $800 \mathrm{~nm}$ at a scanning speed of $600 \mathrm{~nm} / \mathrm{min}$.

\subsubsection{Thermal property analysis}

According to the ASTM E537-2002 standard, the thermal stability of wool fibers was obtained on a TGA Q500 thermogravimetric analyzer (TGA; TA Instruments) in the temperature range of $40-600^{\circ} \mathrm{C}$ at a nitrogen flow rate of $40 \mathrm{ml} / \mathrm{min}$ and a heating rate of $10^{\circ} \mathrm{C} / \mathrm{min}$.

\subsubsection{Scanning electronic microscopy observation}

The morphologies of wool fibers were observed using a Zeiss Merlin Compact field emission scanning electron microscope (FE-SEM) with an acceleration voltage of $10 \mathrm{kV}$.

\subsubsection{Energy-dispersive $X$-ray analysis}

The chemical compositions of wool fibers were analyzed by an energy-dispersive X-ray (EDX) spectroscopy attached to the FE-SEM.

\subsubsection{Frontie Fourier-transform infrared analysis}

The molecular structures of wool fibers were determined using Perkin-Elmer Spotlight 400 and Frontie Fourier-transform infrared (FT-IR) imaging system based on the attenuated total refraction mode in the wavenumber range of $650-4,000 \mathrm{~cm}^{-1}$ at a resolution of $4 \mathrm{~cm}^{-1}$.

\subsubsection{X-ray diffraction analysis}

The crystal structures of wool fibers were investigated on a D/ Max-Rapid II micro-X-ray diffractometer (Rigaku Corporation, Japan) using Cu Ka radiation (40 kV, 200 mA, exposure 800 s). The crystallinity index $(\mathrm{Cl})(\%)$ of wool fibers was calculated by the following Eq. (1) based on Segal's empirical formula [7]:

$$
C I(\%)=\frac{I_{9}-I_{14}}{I_{9}} \times 100 \%
$$

where $I_{9^{\circ}}$ and $I_{14^{\circ}}$ are the diffraction intensities at the $2 \theta$ of $9^{\circ}$ and $14^{\circ}$, respectively.

According to the azimuth diffraction pattern of the $I_{9^{\circ}}$ crystal face, the orientation degree [45], $y$, of wool fibers in the range of $0-180^{\circ}$ was calculated by the following Eq. (2):

$$
y=\frac{180^{\circ}-H W}{180^{\circ}}
$$

where HW is the full width at half maximum of the diffraction peak.

\section{Results and discussion}

\subsection{Tensile property}

The representative stress-strain curves abstracted from the mean values of more than 30 wool fibers (not given) show that all fiber specimens before and after exposure to irradiation have the similar typical stress-strain curves. They are almost overlapped in the initial stress-strain region, which obeys the Hook's law. In the stress-strain plastic region, the stress values of wool fibers decrease to various degrees after being irradiated by UVB, UVA, and visible light irradiation. The W2 specimens' behavior is a little better than the $\mathrm{W} 1$ specimens primarily because of the coating of $\mathrm{TiO}_{2}$ nanoparticles. However, in the stress-strain postyield region, the irradiated $\mathrm{W} 1$ and $\mathrm{W} 2$ specimens are broken down more quickly than the unexposed ones, meaning the cleavage of the molecular chains of wool proteins induced by UV rays or visible light irradiation [7]. Importantly, the prolonged exposure to UVB/UVA rays or visible light would accelerate the photoaging of wool fibers, especially for UVB rays.

\subsubsection{Effects of irradiation time on tensile strength and elongation at break}

The tensile strength and elongation at break of wool fibers are reduced from 1.42 to $1.24 \mathrm{cN} / \mathrm{dtex}$ and from 40.7 to $36.8 \%$ after being coated with $\mathrm{TiO}_{2}$, which is mainly attributed to the 
hydrothermal treatment using hot pressurized water [46] and tetraisopropyl titanate. The impacts of irradiation time on the tensile strength of wool fibers exposed to UVB $\left(0.7 \mathrm{~mW} / \mathrm{cm}^{2}\right)$, UVA $\left(0.26 \mathrm{~mW} / \mathrm{cm}^{2}\right)$, and visible light $(59,500 \mathrm{~lx})$ irradiation are shown in Figure 1A. It is clear that the tensile strengths of W1 and W2 specimens decrease quickly along with the irradiation times at first and then slowly decrease with the increase in irradiation times. It has been demonstrated that the amount of $\alpha$-helical keratin in wool can be reduced to some extent due to the radiation-induced thermal denaturation, which influences the strain-induced $\alpha-\beta$ transformation, and hence the loss of tensile strength of wool fibers occurs [5]. The UVB rays lead the most serious damage to tensile strength of wool fibers in a short time, even though their surfaces are coated with $\mathrm{TiO}_{2}$ nanoparticles in comparison with the UVA rays and visible light. This is because of the very high energy of photons and the large irradiation intensity of UVB rays. The tensile strengths of the W2 specimens decrease by $37 \%$ after $196 \mathrm{~h}$ of UVB, $20 \%$ after $1,440 \mathrm{~h}$ of UVA, and $18 \%$ after $1,800 \mathrm{~h}$ of visible light irradiation, which are smaller than the corresponding values of W1 specimens ( $41 \%$ for UVB, $44 \%$ for UVA, and $50 \%$ for visible light irradiation). But for the long-term UVB rays irradiation over $240 \mathrm{~h}$, the tensile strengths for both $\mathrm{W} 1$ and $\mathrm{W} 2$ specimens reach the same value $0.78 \mathrm{cN} / \mathrm{dtex}$.

The impacts of irradiation time on the elongation at break for wool fibers exposed to UVB $\left(0.7 \mathrm{~mW} / \mathrm{cm}^{2}\right)$, UVA $(0.26 \mathrm{~mW} /$ $\left.\mathrm{cm}^{2}\right)$, and visible light $(59,500 \mathrm{~lx})$ irradiation are shown in Figure 1B. It is evident that as the irradiation times increase, the elongations at break for both fiber specimens decrease under UVB, UVA, and visible light irradiation. The decreased rates of the W1 and W2 specimens exposed to UVB rays are much faster than those exposed to UVA rays and visible light. So, the results imply that the coating of $\mathrm{TiO}_{2}$ nanoparticles plays a certain role in protecting the tensile properties of wool fibers against high-intensity UVB, UVA, and visible light irradiation during a period of time.

\subsubsection{Effect of irradiation intensity}

The effects of irradiation intensity on the tensile properties of wool fibers exposed to three different UVB irradiations for $48 \mathrm{~h}$ are shown in Figure 2. It is obvious that after the identical exposure time, the tensile strength and elongation at break for both fiber specimens decrease along with the increase in irradiation intensity, which is resulted from the more high energy photons of UVB rays. Namely, the higher the irradiation intensity of UVB rays, the more serious $\mathrm{TiO}_{2}$-coated wool fibers are suffered to damage.

\subsection{Yellowness and whiteness indices}

The impacts of irradiation time on the yellowness index of wool fibers under UVB, UVA, and visible light irradiation are shown in Figure $3 A$. The yellowness index of wool fibers increases slightly from 17.8 to 18.1 after being coated with $\mathrm{TiO}_{2}$. It is noticed that the high-intensity UVB rays have a great influence on the yellowness indices of wool fibers. The yellowness
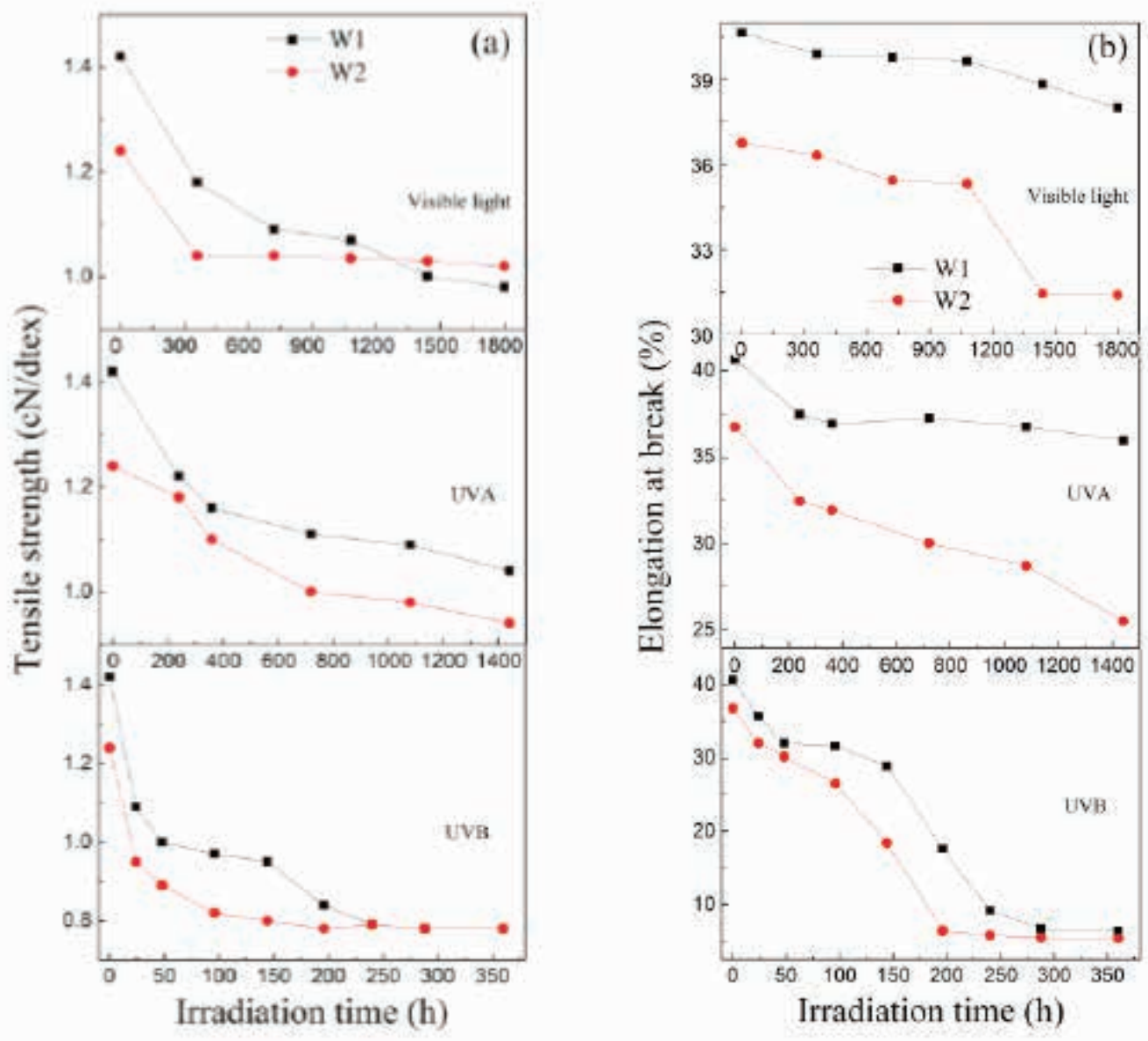

Figure 1. The impacts of irradiation time on (A) tensile strength and (B) elongation at break for wool fibers. 

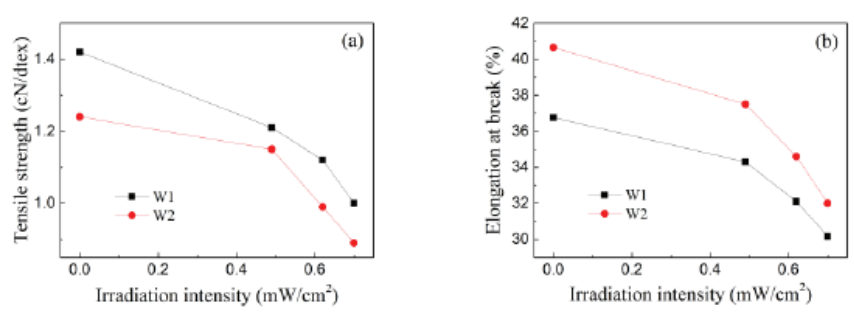

Figure 2. The impacts of irradiation intensity on $(A)$ tensile strength and (B) elongation at break for wool fibers exposed to UVB rays for $48 \mathrm{~h}$.

indices increase quickly with the increase in irradiation time. This is because of the formation of yellow chromophores derived from tryptophan and tyrosine oxidation products [47]. However, the W2 specimens' behavior is much better than the $\mathrm{W} 1$ specimens mainly due to the $\mathrm{TiO}_{2}$ coating. On the contrary, the UVA rays have almost no obvious influence on the yellowness indices of wool fibers whether they are coated with $\mathrm{TiO}_{2}$ nanoparticles or not. It means that the UVA rays cannot destroy the chromophores of wool. For visible light, the yellowness indices for the W1 and W2 specimens have negligible changes with the increase in irradiation time.

The impacts of irradiation time on the whiteness index of wool fibers when exposed to UVB, UVA, and visible light irradiation are shown in Figure 3B. After treatment with tetraisopropyl titanate, the whiteness index of wool fibers decreases from 57.9 to 54.1 . It is noted that the whiteness indices for both W1 and W2 specimens decrease sharply with the increasing irradiation time under UVB irradiation. The W2 specimens' behavior is much better than the W1 specimens. Similarly, the UVA rays and visible light have little influence on the whiteness indices of wool fibers, except the whiteness index of the W2 specimens, which increase slightly at the late period of UVA irradiation primarily because of the photo-bleaching of $\mathrm{TiO}_{2}$ [38]. Therefore, the results confirm that the $\mathrm{TiO}_{2}$ film makes a little contribution to the photo-yellowing of wool fibers against UVB rays.

\subsection{Optical property}

The diffuse reflectance spectra of wool fibers are shown in Figure 4. It is observed that the W1 specimens can absorb UV rays and visible light to some extent, which are associated with the UV- and visible-absorbing chromophores, such as cystine, tryptophan, tyrosine, phenylalanine, and yellow oxidation products [48]. When the wool fibers are treated with tetraisopropyl titanate under the hydrothermal condition, the capability of absorbing UV rays and visible light is slightly improved. The optical absorption edge extends to visible light region owing to the coating of $\mathrm{TiO}_{2}$ nanoparticles. It has been confirmed that the co-doping of carbon, nitrogen, oxygen, and sulfur in the $\mathrm{TiO}_{2}$-modified wool fibers acts as a trapping center for electrons and holes, thereby reducing the recombination rate of charge carriers [49]. The relationship between $(\alpha h v)^{2}$ and incident photon energy $(h v)$ for the W2 specimens is shown in Figure 5, where $\alpha$ is the absorption coefficient. The bandgap of the $\mathrm{TiO}_{2}$-coated wool fibers is estimated as $3.1 \mathrm{eV}$,
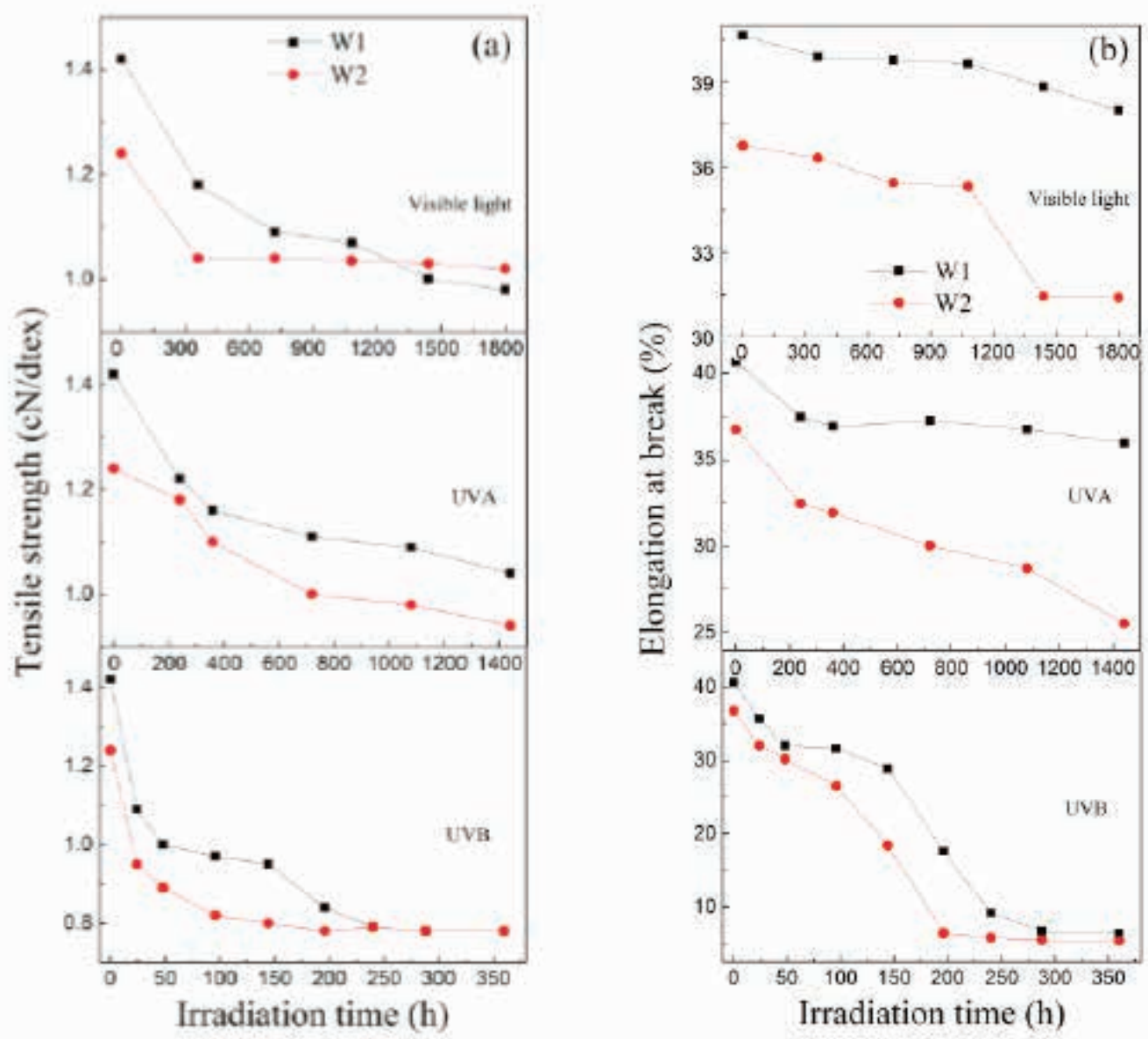

Figure 3. The impacts of irradiation time on (A) yellowness indices and (B) whiteness indices for wool fibers. 


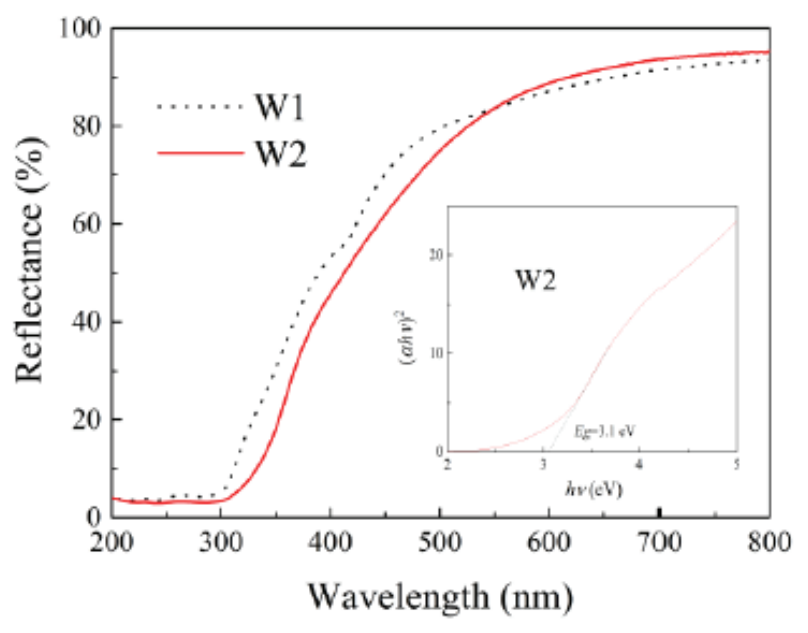

Figure 4. Diffuse reflectance spectra of wool fibers.

which is smaller than $3.2 \mathrm{eV}$ of the theoretical value of anatase $\mathrm{TiO}_{2}$ [39].

\subsection{Thermal stability}

The TGA/DTG curves of wool fibers before and after exposure to UVB $\left(0.7 \mathrm{~mW} / \mathrm{cm}^{2}\right)$, UVA $\left(0.26 \mathrm{~mW} / \mathrm{cm}^{2}\right)$, and visible light $(59,500 \mathrm{Ix})$ irradiation are shown in Figure 5 . It is found that the thermal decomposition for all wool fibers can be classified into two degradation periods. The first thermal degradation period occurred at below $100^{\circ} \mathrm{C}$ is ascribed to the removal of surface absorbed water and residual water molecules in wool fibers and $\mathrm{TiO}_{2}$ particles. The second thermal degradation period is principally located in the region of $200-500^{\circ} \mathrm{C}$, resulting from the decomposition of long polypeptide chains of keratin proteins [27]. When wool fibers are irradiated by UV rays or visible light for specific times, the maximum thermal decomposition temperatures increase about $9-11^{\circ} \mathrm{C}$ from $305^{\circ} \mathrm{C}$ for the $\mathrm{W} 1$ specimens and $2-\sim 4^{\circ} \mathrm{C}$ from $314^{\circ} \mathrm{C}$ for the W2 specimens. UV or visible light irradiation causes the breakdown of long polypeptide chains of keratin proteins to some extent. After irradiation, the onset decomposition temperatures of the $\mathrm{W} 1$ specimens decrease from 245 to $234^{\circ} \mathrm{C}$ for $360 \mathrm{~h}$ of UVB, $243^{\circ} \mathrm{C}$ for $1,440 \mathrm{~h}$ of UVA, and $241^{\circ} \mathrm{C}$ for $1,800 \mathrm{~h}$ of visible

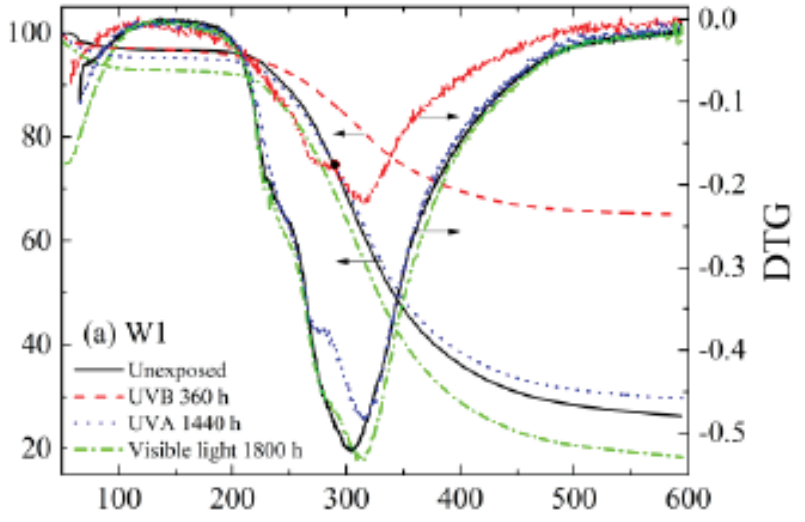

light. The corresponding relative masses are shifted from 26.3 to $65.1 \%$ for $360 \mathrm{~h}$ of UVB, $29.7 \%$ for $1,440 \mathrm{~h}$ of UVA, and $18.5 \%$ for $1,800 \mathrm{~h}$ of visible light. As for the W2 specimens, the onset decomposition temperatures increase about $3-\sim 6^{\circ} \mathrm{C}$ from $242^{\circ} \mathrm{C}$. The corresponding relative masses increase from 21.5 to $28.1 \%$ for $360 \mathrm{~h}$ of UVB, $24.8 \%$ for $1,440 \mathrm{~h}$ of UVA, and $22.9 \%$ for $1,800 \mathrm{~h}$ of visible light. So the TGA/DTG results suggest that the coating of $\mathrm{TiO}_{2}$ nanoparticles makes a certain contribution to the thermal properties of wool fibers against UVB, UVA, and visible light irradiation.

\subsection{Surface morphology}

The scanning electronic microscopy (SEM) images of surface morphology for wool fibers exposed to UVB $\left(0.7 \mathrm{~mW} / \mathrm{cm}^{2}\right)$, UVA $\left(0.26 \mathrm{~mW} / \mathrm{cm}^{2}\right)$, and visible light $(59,500 \mathrm{~lx})$ irradiation at a specific time are shown in Figure 6. As shown in Figure 6A, the unexposed $\mathrm{W} 1$ specimens have the typical overlapping cuticle scales and their complex surfaces are dotted with some small organic fragments. After $360 \mathrm{~h}$ of UVB irradiation, many small cracks are formed on fiber surfaces due to the bombardment of high-energy UVB photons. When the W1 specimens are exposed to UVA rays for $1,440 \mathrm{~h}$, a few tiny cracks are observed on fiber surfaces. That is induced by the breaking of inter- and intra-chains bonds as well as the chain reactions of carbonyl radicals [50]. Under 1,800 h visible light irradiation, besides very few of crevices, several fragments are attached to fiber surfaces.

As illustrated in Figure 6B, a layer of particulate matter is deposited on the surfaces of the unexposed W2 specimens. The high-resolution SEM image indicates that these particulates are constituted with nano- and sub-meter-sized particles. Under $360 \mathrm{~h}$ UVB irradiation, the wool scales are well preserved and the $\mathrm{TiO}_{2}$ particles are maintained on fiber surfaces. After $1,440 \mathrm{~h}$ of UVA rays and $1,800 \mathrm{~h}$ of visible light irradiation, both fiber specimens have no distinct changes in their appearances and their scales are also kept intact. Thus, the coating of $\mathrm{TiO}_{2}$ nanoparticles on fiber surfaces can withstand the photocorrosion of high-intensity UVB and UVA irradiation for a long time.

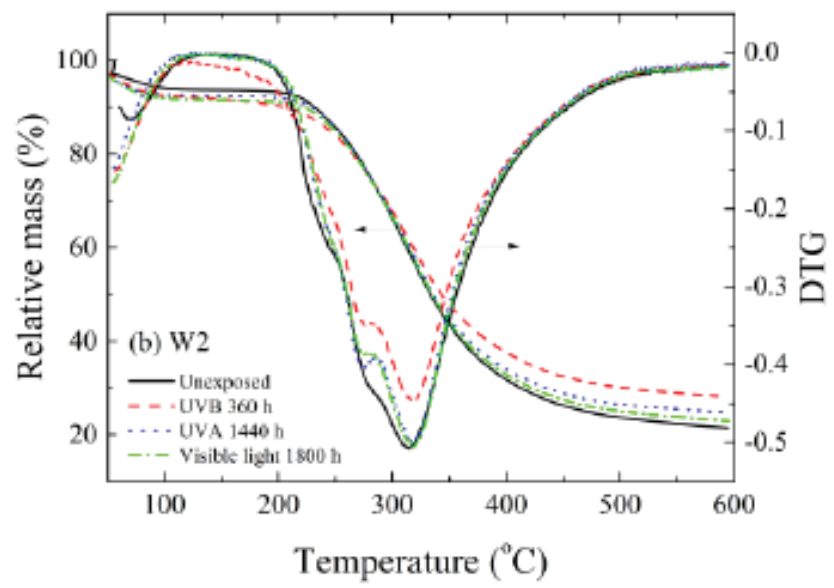




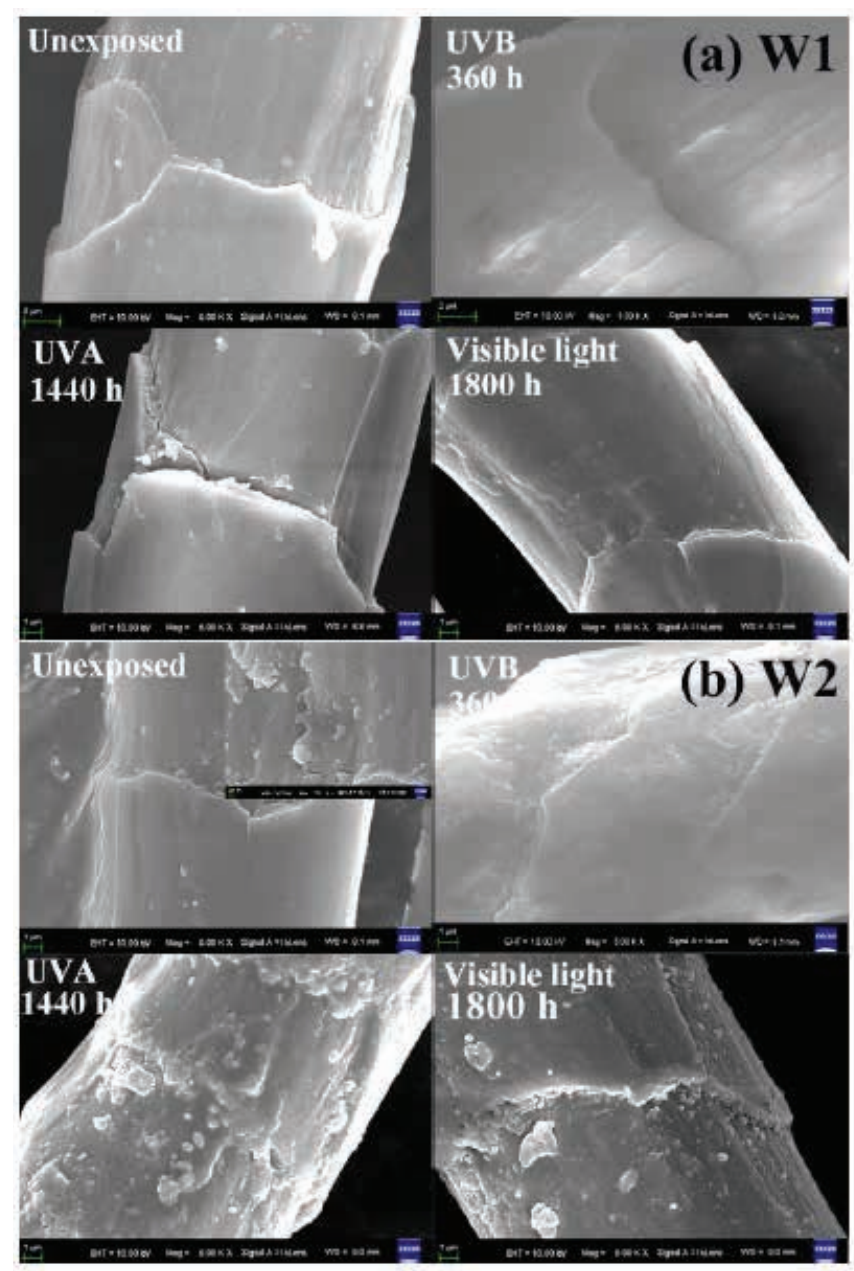

Figure 6. SEM images of (A) W1-untreated and (B) W2-treated wool fibers.

\subsection{Chemical composition}

The chemical compositions of wool fibers before and after exposure to UVB $\left(0.7 \mathrm{~mW} / \mathrm{cm}^{2}\right)$, UVA $\left(0.26 \mathrm{~mW} / \mathrm{cm}^{2}\right)$, and visible light $(59,500 \mathrm{Ix})$ irradiation are summarized in Table 1. In the case of the W1 specimens, the carbon contents increase when exposed to UVB/UVA or visible light irradiation for specific times, whereas the oxygen contents decrease to some extent. Also, the nitrogen content decreases under UVB and UVA irradiation, but it increases slightly under visible light irradiation. Conversely, the sulfur content increases under UVB and UVA irradiation, but it decreases under visible light irradiation. This is because the crystalloid substances are precipitated out of wool fibers [50]. As far as the W2 specimens are concerned, after hydrothermal treatment with tetraisopropyl titanate, the titanium element is introduced into wool fibers. After being exposed to UVB, UVA, and visible light irradiation for specific times, there are various reductions in the contents of carbon, nitrogen, and sulfur, but the oxygen contents increase. This is mainly attributed to the removal of organic components.

\subsection{Molecule structure}

The FT-IR spectra of wool fibers before and after exposure to UVB $\left(0.7 \mathrm{~mW} / \mathrm{cm}^{2}\right)$, UVA $\left(0.26 \mathrm{~mW} / \mathrm{cm}^{2}\right)$, and visible light $(59,500 \mathrm{Ix})$ irradiation are shown in Figure 7 . As for the W1 specimens, the $\mathrm{N}-\mathrm{H}$ stretching vibration at $3,274 \mathrm{~cm}^{-1}$ is
Table 1. The results of chemical compositions of wool fibers

\begin{tabular}{|c|c|c|c|}
\hline \multirow{2}{*}{$\begin{array}{l}\text { Irradiation } \\
\text { condition }\end{array}$} & \multirow[b]{2}{*}{ Elements } & \multicolumn{2}{|c|}{ Weight (\%) } \\
\hline & & $\begin{array}{c}\text { W1 } \\
\text { sample }\end{array}$ & $\begin{array}{c}\text { W2 } \\
\text { sample }\end{array}$ \\
\hline \multirow{5}{*}{ Unexposed } & C & 49.08 & 49.49 \\
\hline & $\mathrm{N}$ & 14.46 & 12.52 \\
\hline & $\mathrm{O}$ & 29.10 & 27.31 \\
\hline & $S$ & 7.35 & 6.33 \\
\hline & $\mathrm{Ti}$ & - & 4.36 \\
\hline \multirow{5}{*}{240 h UVC } & C & 52.21 & 45.68 \\
\hline & $\mathrm{N}$ & 9.97 & 11.51 \\
\hline & $\mathrm{O}$ & 17.25 & 34.65 \\
\hline & $S$ & 20.57 & 3.28 \\
\hline & $\mathrm{Ti}$ & - & 4.88 \\
\hline \multirow{5}{*}{1,440 h UVA } & $\mathrm{C}$ & 54.12 & 45.91 \\
\hline & $\mathrm{N}$ & 12.34 & 11.43 \\
\hline & $\mathrm{O}$ & 19.45 & 32.51 \\
\hline & $\mathrm{S}$ & 14.10 & 5.94 \\
\hline & $\mathrm{Ti}$ & - & 4.21 \\
\hline \multirow{5}{*}{$\begin{array}{c}\text { 1,800 h visible } \\
\text { light }\end{array}$} & $\mathrm{C}$ & 51.05 & 47.68 \\
\hline & $\mathrm{N}$ & 14.90 & 8.95 \\
\hline & $\mathrm{O}$ & 27.33 & 34.66 \\
\hline & $\mathrm{S}$ & 6.72 & 5.17 \\
\hline & $\mathrm{Ti}$ & - & 3.54 \\
\hline
\end{tabular}

broadened after 360 h UVB irradiation. The $\mathrm{CH}_{3}$ asymmetric stretching vibration at $2,960 \mathrm{~cm}^{-1}$ is slightly shifted to $2,962 \mathrm{~cm}^{-}$ 1. The $\mathrm{C}=\mathrm{O}$ stretching vibration at $1,630 \mathrm{~cm}^{-1}$ (amide I) increases to $1,645 \mathrm{~cm}^{-1}$ and the $\mathrm{N}-\mathrm{H}$ bending vibration at $1,515 \mathrm{~cm}^{-1}$ increases to $1,523 \mathrm{~cm}^{-1}$ (amide II), implying the breaking of hydrogen bonds between keratin macromolecules [27]. The $\mathrm{C}-\mathrm{H}$ asymmetric and symmetric bending vibrations at 1,449 and $1,391 \mathrm{~cm}^{-1}$ are weakened to some degree and separated into $1,442,1,414$, and $1,386 \mathrm{~cm}^{-1}$. This is ascribed to the removal of some crystalline substances in wool fibers [50]. The $\mathrm{C}-\mathrm{N}$ stretching vibration at $1,234 \mathrm{~cm}^{-1}$ (amide III) is significantly weakened and decreases to $1,217 \mathrm{~cm}^{-1}$. Furthermore, besides the eliminations of 1,173 and $921 \mathrm{~cm}^{-1}$, the $\mathrm{C}-\mathrm{O}$ stretching vibrations at 1,071 and $1,044 \mathrm{~cm}^{-1}$ are markedly strengthened and shifted to 1,079 and $1,041 \mathrm{~cm}^{-1}$, respectively, indicating the oxidation of sulfur and reduction of cysteic acid residues [6, $8]$, or the breaking of disulfide bond of cystine in wool scales [51], or the breakdown of inter- and intra-molecular chains of wool [50]. Under $1,440 \mathrm{~h}$ of UVA irradiation, the $\mathrm{N}-\mathrm{H}$ absorption band at $3,274 \mathrm{~cm}^{-1}$ increases to $3,277 \mathrm{~cm}^{-1}$. The $\mathrm{CH}_{3}$ and $\mathrm{CH}_{2}$ asymmetric stretching vibrations at 2,960 and 2,927 $\mathrm{cm}^{-1}$ are shifted to 2,962 and $2,934 \mathrm{~cm}^{-1}$, respectively. However, there are no visible changes at bands of $\mathrm{C}=\mathrm{O}, \mathrm{N}-\mathrm{H}$, and $\mathrm{C}-\mathrm{N}$. The $\mathrm{C}-\mathrm{H}$ symmetric bending vibration at $1,391 \mathrm{~cm}^{-1}$ decreases to $1,388 \mathrm{~cm}^{-1}$. Moreover, the $\mathrm{C}-\mathrm{O}$ stretching vibration at $1,071 \mathrm{~cm}^{-}$ 1 increases to $1,077 \mathrm{~cm}^{-1}$. Exposed to visible light irradiation for $1,800 \mathrm{~h}$, the $\mathrm{N}-\mathrm{H}$ stretching vibration increases to $3,276 \mathrm{~cm}^{-}$ 1 and the $\mathrm{CH}_{3}$ asymmetric stretching vibration increases to 

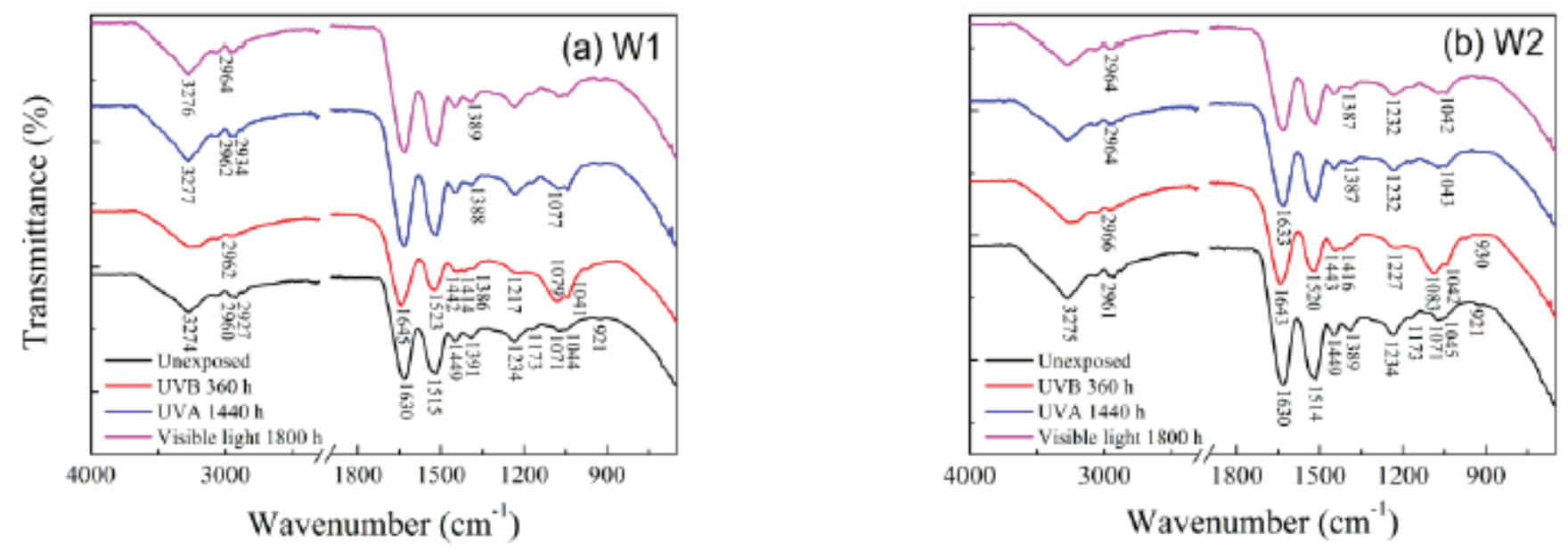

Figure 7. FT-IR spectra of (A) W1-untreated and (B) W2-treated wool fibers.

$2,964 \mathrm{~cm}^{-1}$. Meanwhile, the $\mathrm{C}-\mathrm{H}$ symmetric bending vibration is shifted to $1,389 \mathrm{~cm}^{-1}$.

In comparison with the unexposed $\mathrm{W} 1$ specimens, there is no obvious change for the W2 specimens except for the $\mathrm{C}-\mathrm{H}$ symmetric bending vibration at $1,391 \mathrm{~cm}^{-1}$, which decreases to $1,389 \mathrm{~cm}^{-1}$. After exposure to $360 \mathrm{~h}$ of UVB irradiation, the $\mathrm{N}-\mathrm{H}$ stretching vibration is slightly broadened. The $\mathrm{CH}_{3}$ asymmetric stretching vibration increases to $2,966 \mathrm{~cm}^{-1}$. The $\mathrm{C}=\mathrm{O}, \mathrm{N}-\mathrm{H}$, and $\mathrm{C}-\mathrm{N}$ absorption bands at 1,630,1,514, and $1,234 \mathrm{~cm}^{-}$ 1 are shifted to $1,643,1,520$, and $1,227 \mathrm{~cm}^{-1}$, respectively. The $\mathrm{C}-\mathrm{H}$ asymmetric and symmetric vibrations at 1,449 and $1,389 \mathrm{~cm}^{-1}$ are shifted to 1,443 and $1,416 \mathrm{~cm}^{-1}$, respectively. In addition, the $\mathrm{C}-\mathrm{O}$ stretching vibrations at 1,071, 1,045, and $921 \mathrm{~cm}^{-1}$ are strengthened and shifted to $1,083,1,042$, and $930 \mathrm{~cm}^{-1}$, respectively. Under 1,440 h UVA irradiation, the $\mathrm{CH}_{3}$ asymmetric stretching vibration increases $2,964 \mathrm{~cm}^{-1}$, while the $\mathrm{C}-\mathrm{H}$ symmetric vibration decreases to $1,387 \mathrm{~cm}^{-1}$. The $\mathrm{C}=\mathrm{O}$ and $\mathrm{C}-\mathrm{N}$ absorption bands are shifted to 1,633 and $1,232 \mathrm{~cm}^{-1}$. The $\mathrm{C}-\mathrm{O}$ stretching vibration at $1,045 \mathrm{~cm}^{-1}$ decreases slightly to $1,043 \mathrm{~cm}^{-1}$. After $1,800 \mathrm{~h}$ of visible light illumination, the $\mathrm{CH}_{3}$ asymmetric stretching vibration increases to $2,964 \mathrm{~cm}^{-1}$ and the $\mathrm{C}-\mathrm{H}$ symmetric vibration decreases to $1,387 \mathrm{~cm}^{-1}$. The C-N stretching vibration is shifted to $1,232 \mathrm{~cm}^{-1}$. The $\mathrm{C}-\mathrm{O}$ stretching vibration at $1,045 \mathrm{~cm}^{-1}$ decreases to $1,042 \mathrm{~cm}^{-1}$. In brief, it can be concluded that UVB, UVA, and visible light irradiation result in the photo-oxidation deterioration of the secondary structure of $\mathrm{TiO}_{2}$-coated wool fibers to a more or less degree, which greatly depends on the irradiance, irradiation time, and irradiation wavelengths. The short-wave UVB rays would cause more serious damage to the structurally disordered degree of wool than long-wave UVA rays and visible light.

\subsection{Crystallinity and orientation}

The two-dimensional X-ray diffraction (XRD) images, XRD curves, and orientation curves of wool fibers before and after exposure to UVB $\left(0.7 \mathrm{~mW} / \mathrm{cm}^{2}\right)$, UVA $\left(0.26 \mathrm{~mW} / \mathrm{cm}^{2}\right)$, and visible light $(59,500 \mathrm{Ix})$ irradiation are shown in Figures $8-10$, respectively. It is seen in Figure 8 that the arc-shaped diffraction image of the unexposed $\mathrm{W} 1$ specimens directly reveals the oriented crystal structure and the crystalline state of wool [52]. The preferred orientation of the keratin molecules is located at the angles of $0^{\circ}\left(180^{\circ}\right)$ and $90^{\circ}\left(270^{\circ}\right)$. After exposure to UVB (360 h) or UVA $(1,440 \mathrm{~h})$ or visible light $(1,800 \mathrm{~h})$ irradiation, the brightness of spots at $0^{\circ}\left(180^{\circ}\right)$ becomes dull and the small arc rings at $90^{\circ}\left(270^{\circ}\right)$ are almost disappeared. It means that the preferred orientation of wool is weakened to some extent, namely the orientation of the keratin molecules becomes random. A similar phenomenon is also found in the W2 specimens. It is known that the wool fibers are constituted with long-chain polypeptides held together by the covalent and electrovalent cross-linkages. The valence forces vary according to the type of linkage, and the electrovalent forces include Coulomb forces and Van del Vaal's forces [53]. Therefore, the long-term illumination under UVB/UVA rays or visible light would disorder the margin of $\alpha$-helical crystalline phase and cause the part of $\beta$-helical crystals irregularity [54], leading to the degradation of tensile properties of wool fibers.

It is worth noticing in Figure 9 that in comparison with the W1 specimens, besides the characteristic diffraction peaks at around $9^{\circ}$ (the equatorial reflections of $0.98 \mathrm{~nm}$ for $\alpha$-helix and $\beta$-sheet structure) and $20^{\circ}$ (the meridional reflections of $0.51 \mathrm{~nm}$ for $\alpha$-helix structure and the equatorial reflections of $0.465 \mathrm{~nm}$ for $\beta$-sheet structure) of wool [30], a series of small diffraction peaks are observed in the XRD curves of the W2 specimens. The diffraction peaks occurred at $25^{\circ}, 38^{\circ}, 48^{\circ}, 54^{\circ}, 55^{\circ}, 63^{\circ}$, and $75^{\circ}$ are assigned to the (101), (004), (200), (105), (211), (204), and (215) crystalline planes of anatase $\mathrm{TiO}_{2}$ (JCPDS No 21-1272) [55]. As shown in Table 2, the crystallinity indices of the W1 specimens decrease from 34.7 to $29.7 \%$ after $360 \mathrm{~h}$ of UVB, $26.5 \%$ after $1,440 \mathrm{~h}$ of UVA, and $31.8 \%$ after $1,800 \mathrm{~h}$ of visible light irradiation. When the wool fibers are treated with tetraisopropyl titanate, the $\mathrm{Cl}$ of the W2 specimens decreases to $34.2 \%$. After being irradiated by UVB, UVA, and visible light irradiation, the crystallinity indices further decrease to $22.9 \%$ after $360 \mathrm{~h}$ of UVB, $27.0 \%$ after $1,440 \mathrm{~h}$ of UVA, and $27.8 \%$ after $1,800 \mathrm{~h}$ of visible light irradiation.

The orientation curves in Figure 10 make clear that the orientation structure of wool fibers is changed to some degree after being treated with tetraisopropyl titanate, especially 


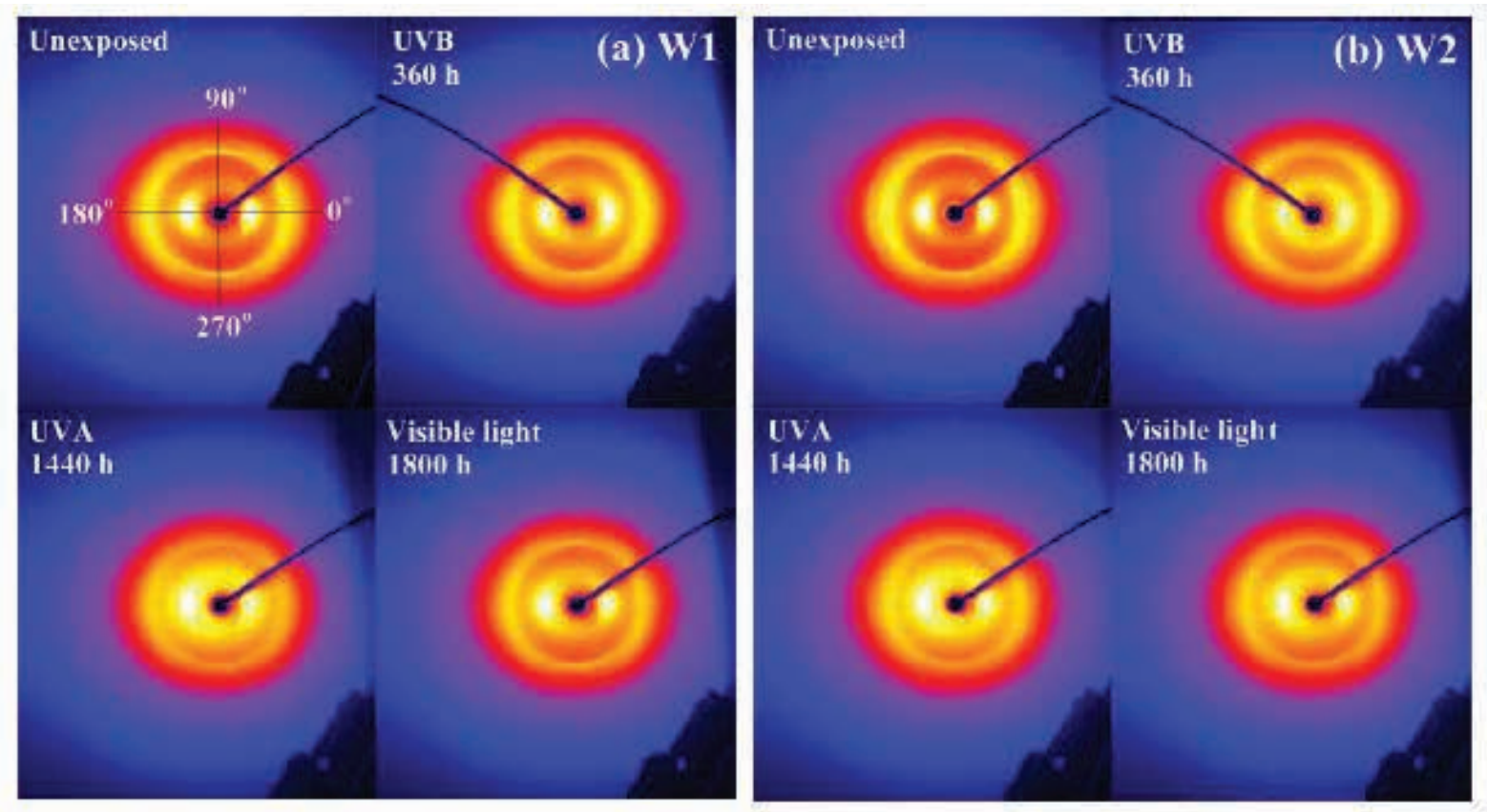

Figure 8. Two-dimensional X-ray diffraction images of (A) W1-untreated and (B) W2-treated wool fibers.
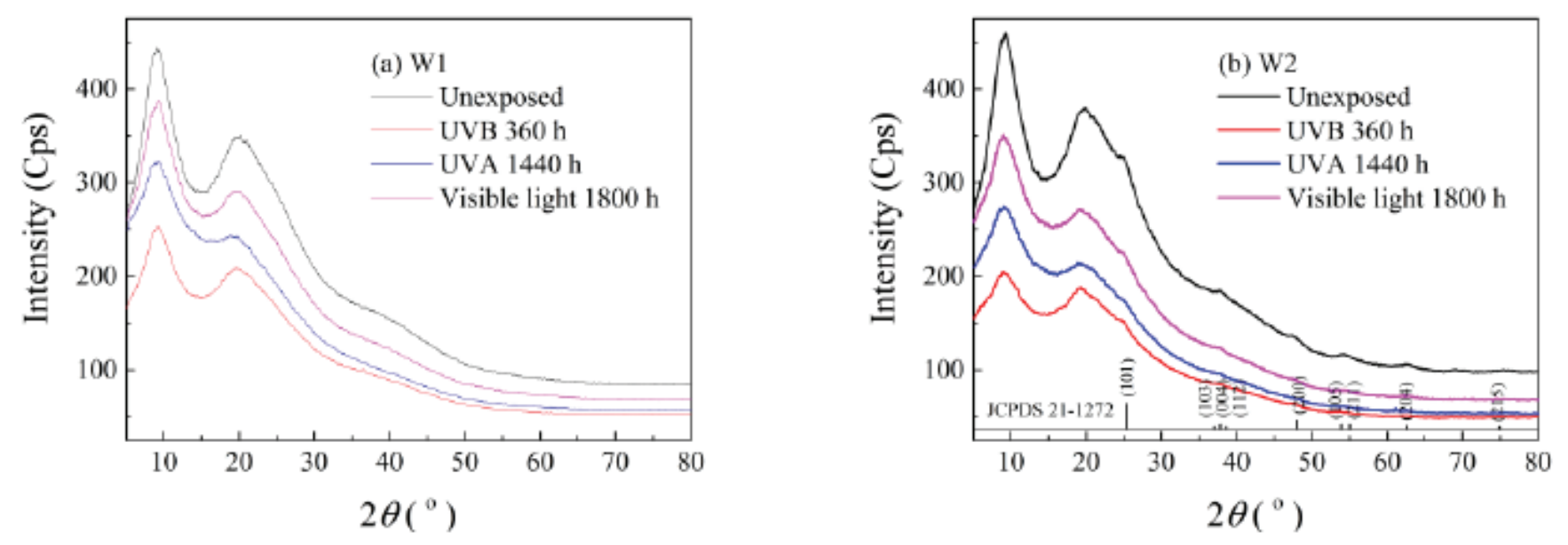

Figure 9. XRD curves of (A) W1-untreated and (B) W2-treated wool fibers.
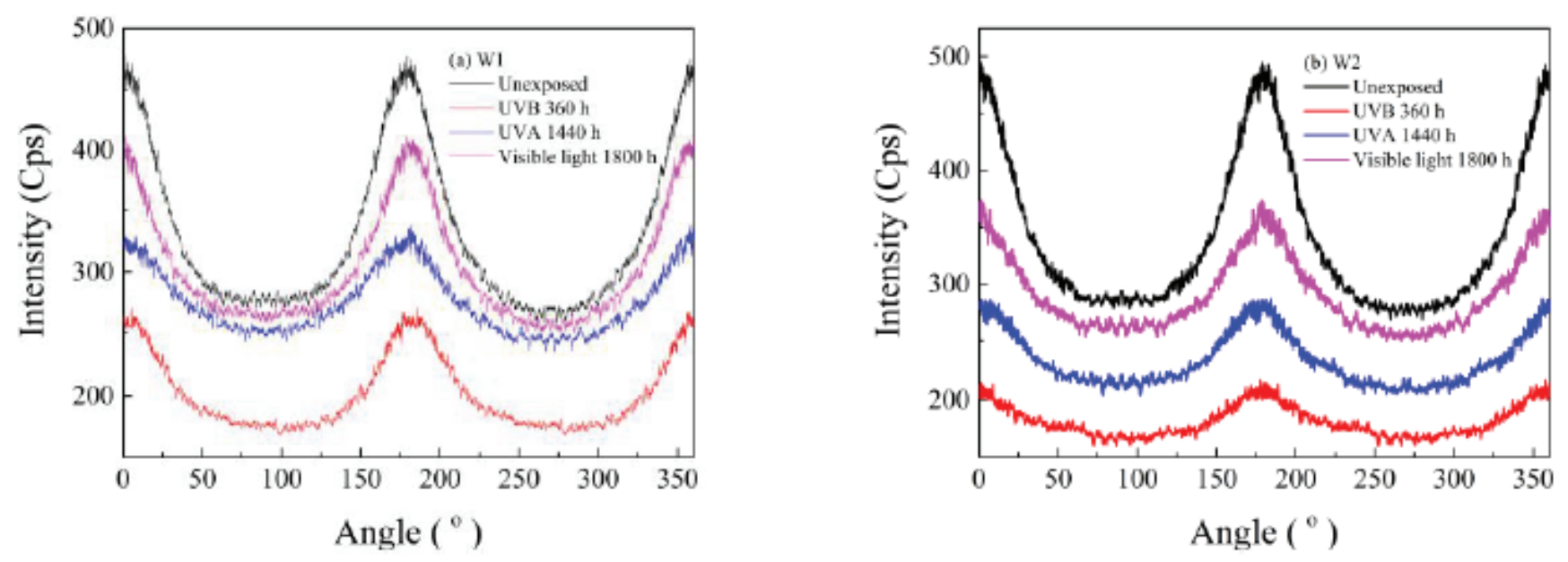

Figure 10. Orientation curves of (A) W1-untreated and (B) W2-treated wool fibers.

when they are exposed to UVB/UVA rays or visible light. The orientation degrees (see Table 2) of the W1 specimens decrease from 0.726 to 0.715 after $360 \mathrm{~h}$ of UVB, 0.666 after $1,440 \mathrm{~h}$ of UVA, and 0.72 after $1,800 \mathrm{~h}$ of visible light 
Table 2. The results of the crystallinity index and orientation degree for wool fibers

\begin{tabular}{|c|c|c|c|}
\hline $\begin{array}{c}\text { Wool } \\
\text { fibers }\end{array}$ & $\begin{array}{c}\text { Irradiation } \\
\text { condition }\end{array}$ & $\begin{array}{c}\text { Crystallinity } \\
\text { index (\%) }\end{array}$ & $\begin{array}{c}\text { Orientation } \\
\text { degree }\end{array}$ \\
\hline \multirow{4}{*}{ W1 } & Unexposed & 34.7 & 0.726 \\
\cline { 2 - 4 } & UVC 240 h & 29.7 & 0.715 \\
\cline { 2 - 4 } & UVA 1,440 h & 26.5 & 0.666 \\
\cline { 2 - 4 } & $\begin{array}{c}\text { Visible light } \\
1,800 \mathrm{~h}\end{array}$ & 31.8 & 0.720 \\
\hline \multirow{4}{*}{ W2 } & Unexposed & 34.2 & 0.734 \\
\cline { 2 - 4 } & UVC 240 h & 22.9 & 0.700 \\
\cline { 2 - 4 } & UVA 1,440 h & 27.0 & 0.698 \\
\cline { 2 - 4 } & $\begin{array}{c}\text { Visible light } \\
1,800 \mathrm{~h}\end{array}$ & 27.8 & 0.697 \\
\hline
\end{tabular}

irradiation. The decreases in orientation for the irradiated wool fibers are assigned to the scission of peptide chains, resulting from the short-chain molecules [7]. The orientation degree of the W2 specimens increases to 0.734 after being treated with tetraisopropyl titanate. The orientation degrees of the W2 specimens decrease to 0.70 after $360 \mathrm{~h}$ of UVB, 0.698 after $1,440 \mathrm{~h}$ of UVA, and 0.697 after $1,800 \mathrm{~h}$ of visible light irradiation. As a result, high-intensity UVB, UVA, and visible light irradiation can lead to the destruction of wool fibers whether it is coated with $\mathrm{TiO}_{2}$ nanoparticles or not.

\section{Conclusions}

To sum up, $\mathrm{TiO}_{2}$-coated wool fibers are irradiated under highintensity UVB, UVA, and visible light irradiation. The results of tensile and yellowness and whiteness indices indicate that the tensile strength and elongation at break of $\mathrm{TiO}_{2}$-coated wool fibers decrease significantly when exposed to UVB rays for a certain time. The high energy UVB irradiation causes much more damage to wool fibers than UVA rays and visible light. However, the $\mathrm{TiO}_{2}$ coating can protect wool fibers from highintensity UVB, UVA, and visible light to a more or less degree. After irradiation, the postyield region of the stress-strain curve of $\mathrm{TiO}_{2}$-coated wool fibers is lost. The coating of $\mathrm{TiO}_{2}$ can almost not withstand the photo-yellowing of wool fibers against UVB rays compared with UVA rays and visible light. TGA/DTG results indicate that the $\mathrm{TiO}_{2}$ coating facilitates the thermal stability of wool fibers when exposed to UVB/UVA rays or visible light. SEM, EDX, FT-IR, and XRD indicate that the coating of $\mathrm{TiO}_{2}$ is constituted with anatase $\mathrm{TiO}_{2}$ nanoparticles and organic components. The morphology of wool fibers can be well preserved by the $\mathrm{TiO}_{2}$ coating under the high-intensity UVB, UVA, and visible light irradiation. However, the chemical composition and molecule structure of $\mathrm{TiO}_{2}$-coated wool fibers are changed. The crystallinity indices and orientation degrees of $\mathrm{TiO}_{2}$-coated wool fibers are reduced too.

\section{Acknowledgements}

This study has been supported by the National Natural Science Foundation of China (No. 51873169) and the Sanqin Scholar Foundation (2017).

\section{References}

[1] Kim, J. I., David, S. K. (1992). The photostability of shrinkproofing polymer systems on wool fabric. Polymer Degradation and Stability, 38(2), 131-137.

[2] Lee, W. S. (2009). Photoaggravation of hair aging. International Journal of Trichology, 1(2), 94-99.

[3] Millington, K. R., Church, J. S. (1997). The photodegradation of wool keratin II. Proposed mechanisms involving cystine. Journal of Photochemistry and Photobiology B: Biology, 39(3), 204-212.

[4] Launer, H. F., (1965). Effect of light upon wool. Part IV: Bleaching and yellowing by sunlight. Textile Research Journal, 35(5), 395-400.

[5] Schmidt, H., Wortmann, F. J. (1994). High pressure differential scanning calorimetry and wet bundle tensile strength of weathered wool. Textile Research Journal, 64(11), 690-695.

[6] Church, J. S., Millington, K. R. (1996). Photodegradation of wool keratin: Part 1. Vibrational spectroscopic studies. Biospectroscopy, 2(4), 249-258.

[7] El-Zaher, N. A., Micheal, M. N. (2002). Time optimization of ultraviolet-ozone pretreatment for improving wool fabrics properties. Journal of Applied Polymer Science, 85(7), 1469-1476.

[8] Periolatto, M., Ferrero, F., Migliavacca, G. (2014). Low temperature dyeing of wool fabric by acid dye after UV irradiation. The Journal of the Textile Institute, 105(10), 1058-1064.

[9] Lennox, F. G., King, M. G., Leaver, I. H., Ramsay, G. C., Savige, W. E. (1971). Mechanisms, prevention, and correction of wool photo-yellowing. Applied Polymer Symposia, 18, 353-369.

[10] Andrady, A. L., Harnid, S. H., Hu, X., Torikai, A. (1995). Effects of increased solar ultraviolet radiation on materials. Journal of Photochemistry and Photobiology B Biology, 24(3), 191-196.

[11] Millington, K. R. (2006). Photoyellowing of wool. Part 1: Factors affecting photoyellowing and experimental techniques. Coloration Technology, 122(4), 169-186.

[12] Dyer, J. M., Bringans, S. D., Bryson, W. G. (20061). Characterisation of photo-oxidation products within photoyellowed wool proteins: Tryptophan and tyrosine derived chromophores. Photochemical \& Photobiological Sciences, 5(7), 698-706.

[13] Nogueira, A. C. S., Richena, M., Dicelio, L. E., Joekes, I. (2007). Photo yellowing of human hair. Journal of Photochemistry and Photobiology B: Biology, 88(2-3), 119125.

[14] Zhang, H., Millington, K. R., Wang, X. G. (2008). A morphology-related study on photodegradation of protein fibres. Journal of Photochemistry and Photobiology B: Biology, 92(3), 135-143. 
[15] Zhang, H., Deb-Choudhury, S. (2013). The effect of wool surface and interior modification on subsequent photostability. Journal of Applied Polymer Science, 127(5), 3435-3440.

[16] Millington, K. R. (2016). Photoyellowing of wool. Part 2: Photoyellowing mechanisms and methods of prevention. Coloration Technology, 122(6), 301-316.

[17] Riedel, J. H., Hocker, H. (1996). Multifunctional polymeric UV absorbers for photostabilization of wool. Textile Research Journal, 66(11), 684-689.

[18] Jones, D. C., Carr, C. M., Cooke, W. D., Lewis, D. M. (1998). Investigating the photo-oxidation of wool using FT-Raman and FT-IR spectroscopies. Textile Research Journal, 68(10), 739-748.

[19] Millington, K. R., Giudice, M. D., Sun, L. (2014). Improving the photostability of bleached wool without increasing its yellowness. Coloration Technology, 130(6), 413-417.

[20] Montazer, M. Pakdel, E. (20112). Functionality of nano titanium dioxide on textiles with future aspects: Focus on wool. Journal of Photochemistry and Photobiology C-Photochemistry Reviews, 12(4), 293-303.

[21] Pakdel, E., Daoud, W. A., Wang, X. G. (2015). Assimilating the photo-induced functions of TiO2-based compounds in textiles: Emphasis on the sol-gel process. Textile Research Journal, 85(13), 1404-1428.

[22] Montazer, M., Amiri, M. M., Reza, M. A. M. (2013). In situ synthesis and characterization of nano $\mathrm{ZnO}$ on wool: Influence of nano photo reactor on wool properties. Photochemistry and Photobiology, 89(5), 1057-1063.

[23] Zhang, M. W., Tang, B., Sun, L., Wang, X. G. (20142). Reducing photoyellowing of wool fabrics with silica coated ZnO nanoparticles. Textile Research Journal, 84(17), 8401848.

[24] Baaka, N., Ben Ticha, M., Haddar, W., Amorim, M. T. P., Mhenni, M. F. (2018). Upgrading of UV protection properties of several textile fabrics by their dyeing with grape pomace colorants. Fibers and Polymers, 19(2), 307-312.

[25] Masakazu, A. Masato, T. (2003). The design and development of highly reactive titanium oxide photocatalysts operating under visible light irradiation. Journal of Catalysis, 216(1), 505-516.

[26] Yang, H. Y., Zhu, S. K., Pan, N. (2004). Studying the mechanisms of titanium dioxide as ultraviolet-blocking additive for films and fabrics by an improved scheme. Journal of Applied Polymer Science, 92(5), 3201-3210.

[27] Hsieh, S. H., Zhang, F. R., Li, H. S. (2006). Anti-ultraviolet and physical properties of woolen fabrics cured with citric acid and TiO2/chitosan. Journal of Applied Polymer Science, 100(6), 4311-4319.

[28] Tung, W. S., Daoud, W. A., Leung, S. K. (2009). Understanding photocatalytic behavior on biomaterials: Insights from TiO2 concentration. Journal of Colloid and Interface Science, 339(2), 424-433.

[29] Siwinska-Stefanska, K., Ciesielczyk, F., KołodziejczakRadzimska, A., Paukszta, D., Sojka-Ledakowicz, J., et al. (2012). TiO2-SiO2 inorganic barrier composites: From synthesis to application. Pigment \& Resin Technology, 41(3), 139-148.
[30] Niu, M., Liu, X. G., Dai, J. M., Hou, W. S., Wei, L. Q., et al. (2012). Molecular structure and properties of wool fiber surface-grafted with nano-antibacterial materials. Spectrochimica Acta Part A: Molecular and Biomolecular Spectroscopy, 86, 289-293.

[31] McNeil, S. J., Sunderland, M. R. (2016). The nanocidal and antifeedant activities of titanium dioxide desiccant toward wool-digesting Tineola bisselliella moth larvae. Clean Technologies and Environmental Policy, 18(3), 843-852.

[32] Sunderland, M. R., McNeil, S. J. (2017). Protecting wool carpets from beetle and moth larvae with nanocidal titanium dioxide desiccant. Clean Technologies and Environmental Policy, 19(4), 1205-1213.

[33] Montazer, M., Pakdel, E. (20111). Self-cleaning and color reduction in wool fabric by nano titanium dioxide. Journal of the Textile Institute, 102(4), 343-352.

[34] Liu, J., Wang, Q., Fan, X. R. (2012). Layer-by-layer selfassembly of TiO2 sol on wool to improve its anti-ultraviolet and anti-ageing properties. Journal of Sol-Gel Science and Technology, 62(3), 338-343.

[35] Zhang, H., Millington, K. R., Wang, X. G. (2009). The photostability of wool doped with photocatalytic titanium dioxide nanoparticles. Polymer Degradation and Stability, 94(2), 278-283.

[36] Montazer, M., Pakdel, E. (2010). Reducing photoyellowing of wool using nano TiO2. Photochemistry and Photobiology, 86(2), 255-260.

[37] Montazer, M., Pakdel, E., Moghadam, M. B. (2011). The role of nano colloid of TiO2 and butane tetra carboxylic acid on the alkali solubility and hydrophilicity of proteinous fibers. Colloids and Surfaces A: Physicochemical and Engineering Aspects, 375(1-3), 1-11.

[38] Montazer, M., Morshedi, S. (2014). Photo bleaching of wool using nano TiO2 under daylight irradiation. Journal of Industrial and Engineering Chemistry, 20(1), 83-90.

[39] Behzadnia, A., Montazer, M., Rashidi, A., Rad, M. M. (2014). Rapid sonosynthesis of $\mathrm{N}$-doped nano TiO2 on wool fabric at low temperature: Introducing self-cleaning, hydrophilicity, antibacterial/antifungal properties with low alkali solubility, yellowness and cytotoxicity. Photochemistry and Photobiology, 90(6), 1224-1233.

[40] Montazer, M., Seifollahzadeh, S. (2011). Enhanced selfcleaning, antibacterial and UV protection properties of nano TiO2 treated textile through enzymatic pretreatment. Photochemistry and Photobiology, 87(4), 877-883.

[41] Haji, A., Shoushtari, A. M., Mazaheri, F., Tabatabaeyan, S. E. (2016). RSM optimized self-cleaning nano-finishing on polyester/wool fabric pretreated with oxygen plasma. The Journal of the Textile Institute, 107(8), 985-994.

[42] Behzadnia, A., Montazer, M., Rad, M. M. (2016). In situ photo sonosynthesis of organic/inorganic nanocomposites on wool fabric introducing multifunctional properties. Photochemistry and Photobiology, 92(1), 76-86.

[43] Zhang, M. W., Xie, W. J., Tang, B., Sun, L., Wang, X. G. (2017). Synthesis of TiO2\&SiO2 nanoparticles as efficient UV absorbers and their application on wool. Textile Research Journal, 87(14), 1784-1792.

[44] Aksakal, B., Koc, K., Bozdogan, A., Tsobkallo, K. (2013). Uniaxial tensile properties of TiO2 coated single wool fibers by sol-gel method: The effect of heat treatment. Journal of Applied Polymer Science, 130(2), 898-907. 
[45] Bohn, A., Fink, H. P., Ganster, J., Pinnow, M. (2000). $X$-ray texture investigations of bacterial cellulose. Macromolecular Chemistry and Physics, 201(15), 19131921.

[46] Zhang, H., Sun, R. J., Zhang, X. T. (2014). Effect of hydrothermal processing on the structure and properties of wool fibers. Industria Textila, 65(3), 123-128.

[47] Dyer, J. M., Bringans, S. D., Bryson, W. G. (2006). Determination of photooxidation products within photoyellowed bleached wool proteins. Photochemistry and Photobiology, 82(2), 551-557.

[48] Millington, K. R. (2012). Diffuse reflectance spectroscopy of fibrous proteins. Amino Acids, 43(3), 1277-1285.

[49] Zhang, H., Yang, Z. W., Zhang, X. T., Mao, N. T. (2014). Photocatalytic effects of wool fibers modified with solely TiO2 nanoparticles and $\mathrm{N}$-doped $\mathrm{TiO} 2$ nanoparticles by using hydrothermal method. Chemical Engineering Journal, 254(7), 106-114.

[50] Zeng, Y., Liu, Y., Liu, J. J., Zheng, H. L., Zhou, Y., et al. (2015). Application of electron paramagnetic resonance spectroscopy, Fourier transform infrared spectroscopyattenuated total reflectance and scanning electron microscopy to the study of the photo-oxidation of wool fiber. Analytical Methods, 7(24), 10403-10408.
[51] Xu, B. S., Niu, M., Wei, L. Q., Hou, W. S., Liu, X. G. (2007). The structural analysis of biomacromolecule wool fiber with Ag-loading SiO2 nano-antibacterial agent by UV radiation. Journal of Photochemistry and Photobiology A: Chemistry, 188(1), 98-105.

[52] Shi, K. H., Ye, L., Li, G. X. (2015). Structure and hydrothermal stability of highly oriented polyamide 6 produced by solid hot stretching. RSC Advances, 5(38), 30160-30169.

[53] Sookne, A. M., Harris, M. (1937). Stress-strain characteristics of wool as related to its chemical constitution. Journal of Research of the National Bureau of Standards, 19, 535-549.

[54] Xiao, X. L., Hu, J. L. (2016). Influence of sodium bisulfite and lithium bromide solutions on the shape fixation of camel guard hairs in slenderization process. International Journal of Chemical Engineering, 2016, 1-11.

[55] Yang, W. G., Wang, Y. L., Shi, W. M. (2012). One-step synthesis of single-crystal anatase TiO2 tetragonal facetednanorods for improved-performance dye-sensitized solar cells. CrystEngComm, 14(1), 230-234. 